\title{
WATER RESOURCES STATUS AND AVAILABILITY ASSESSMENT IN CURRENT AND FUTURE CLIMATE CHANGE SCENARIOS FOR BEAS RIVER BASIN OF NORTH WESTERN HIMALAYA
}

\author{
S.P.Aggarwal ${ }^{\mathrm{a}, *}$, Praveen K. Thakur ${ }^{\mathrm{a}}$, Vaibhav Garg ${ }^{\mathrm{a}}$, Bhaskar R. Nikamª, Arpit Chouksey ${ }^{\mathrm{a}}$, Pankaj Dhote ${ }^{\mathrm{a}}$, and Tanmoyee \\ Bhattacharya $^{\mathrm{a}}$
}

\author{
${ }^{a}$ Water Resources Department, Indian Institute of Remote Sensing, ISRO, Dehradun-248001, \\ (spa*, praveen, vaibhav, bhaskarnikam, arpit, prd)@iirs.gov.in, bhattacharya.tanmoyee36@gmail.com
}

\author{
Commission VIII, WG VIII/4
}

KEY WORDS: Water balance, Beas river basin, snow melt runoff, glacier melt, Himalaya

\begin{abstract}
:
The water resources status and availability of any river basin is of primary importance for overall and sustainable development of any river basin. This study has been done in Beas river basin which is located in North Western Himalaya for assessing the status of water resources in present and future climate change scenarios. In this study hydrological modelling approach has been used for quantifying the water balance components of Beas river basin upto Pandoh. The variable infiltration capacity (VIC) model has been used in energy balance mode for Beas river basin at $1 \mathrm{~km}$ grid scale. The VIC model has been run with snow elevation zones files to simulate the snow module of VIC. The model was run with National Centre for Environmental Prediction (NCEP) forcing data (Tmax, Tmin, Rainfall and wind speed at 0.5degree resolution) from 1 Jan. 1999 to 31 Dec 2006 for calibration purpose. The additional component of glacier melt was added into overall river runoff using semi-empirical approach utilizing air temperature and glacier type and extent data. The ground water component is computed from overall recharge of ground water by water balance approach. The overall water balance approach is validated with river discharge data provided by Bhakra Beas Management Board (BBMB) from 1994-2014. VIC routing module was used to assess pixel wise flow availability at daily, monthly and annual time scales. The mean monthly flow at Pandoh during study period varied from $19-1581 \mathrm{~m}^{3} / \mathrm{s}$ from VIC and 50 to $1556 \mathrm{~m}^{3} / \mathrm{sec}$ from observation data, with minimum water flow occurring in month of January and maximum flow in month of August with annual $\mathrm{R}^{2}$ of 0.68. The future climate change data is taken from CORDEX database. The climate model of NOAA-GFDL-ESM2M for IPCC RCP scenario 4.5 and 8.5 were used for South Asia at $0.44 \mathrm{deg}$. grid from year 2006 to 2100 . The climate forcing data for VIC model was prepared using daily maximum and minimum near surface air temperature, daily precipitation and daily surface wind speed. The GFDL model also gives validation phase scenarios from 2006 to 2015, which are used to test the overall model performance with current data. The current assessment made by hydrological water balance based approach has given reasonable good results in Beas river basin. The main limitation of this study is lack of full representation of glacier melt flow using fully energy balance model. This component will be addressed in coming time and it will be integrated with tradition hydrological and snowmelt runoff models. The other limitation of current study is dependence on NCEP or other reanalysis of climate forcing data for hydrological modelling, this leads to mismatch between actual and simulated water balance components. This problem can be addressed if more ground based and fine resolution grid based hydro meteorological data are used as input forcing data for hydrological modelling.
\end{abstract}

\section{INTRODUCTION}

The availability of water in India is highly erratic both spatially and temporally, due to different topographical features and its diverse climate. The country receives $4,000 \mathrm{~km}^{3}$ of estimated annual precipitation including snowfall. However, as per the Central Water Commission (CWC), India, the major river system wise estimates of the surface runoff potential is about $1,869 \mathrm{~km}^{3}$. It is also reported that approximately $1123 \mathrm{~km}^{3}$ are being used as surface water and groundwater resources for beneficial purposes. However, Garg and Hassan (2007) contradict this estimation and assessed only around $688 \mathrm{~km}^{3}$ as utilisable water resource. The Ganga-Brahmaputra-Meghna rivers system, which is a major contributor to water resources potential of the country, utilizes $40 \%$ of surface water resources. It was noticed that the utilization of surface water is very less for the non-classified river basins namely Narmada, Godavari, Mahanadi, Krishna, Western ghats, Pennar and Cauvery (Garg and Hassan 2007; Mall et al. 2007; Mujumdar 2008; CWC 2012).
The water resources of the developing India have also been examined in the context of the growing population by Gupta and Deshpande (2004). The international agencies considered the availability of less than $1,000 \mathrm{~m}^{3}$ per capita as scarcity condition (Gosain et al. 2006; CWC 2009). The national per capita annual availability of water is $1,731 \mathrm{~m}^{3}$ as per the distribution of water resources potential in the country (CWC 2012). The average availability in Brahmaputra and Barak basin was as high as $14,057 \mathrm{~m}^{3}$ while it was as low as $308 \mathrm{~m}^{3}$ in Sabarmati basin (CWC 2012). Per capita annual availability for the rest of the country excluding Brahmaputra and Barak basin works out to about $1,345 \mathrm{~m}^{3}$, which shows that a large part of the country is water stressed. Cauvery, Sabarmati, East flowing rivers and west flowing rivers are some of the basins which fall into this category (Gosain et al. 2006; Mujumdar 2008; CWC 2012). Moreover, the developmental activities going on in the country affect the land cover pattern and its climatic regime through feedback mechanism, which again put stress on the future water availability. Considering all these aspects, it is crucial to assess the present water resources and impact of 
climate change of hydrological regime of major basins in the country.

In order to develop and rationally manage the water resources, a quantity and quality assessment of water is necessary. The international Glossary of Hydrology (UNESCO/WMO, 1992) defines water resources assessment (WRA) as the "determination of sources, extent, dependability and quality of water resources for their utilization and control". In reference to evaluate the dynamics of the water resource related to human impacts or demand, WRA can be used as a water resources evaluation tool. Water resources of basin is reckoned by the natural flow in a river basin. "Water resources assessment aims to measure quantity and quality of the water in a system, including data collection, data validation, and water accounting techniques, using both ground and remote sensing" (www.unesco-ihe.org). In order to achieve systematic WRA of a basin, it requires large data with high accuracy. But practically, it is not possible to obtain the ground data with such accuracy and interval as required for the assessment. In such scenarios, remote sensing and GIS technique combined with hydrological modelling plays a vital role for accurate and correctly formatted data collection and for future assessment. Advantage in satellite derived data is the consistency in terms of temporal and spatial extent. Another advantage of the data obtained from remote sensing is that it can be easily incorporated into the hydrological models. This helps in achieving more accurate estimates of the Water balance components.

In the present study, Beas River basin which is located in North Western Himalaya is selected as study area. The basin scale water resources assessment has been done using hydrological modelling approach. For the present analysis variable infiltration capacity (VIC) model has been used. VIC is a semidistributed macroscale hydrological model designed to represent surface energy, hydrological fluxes and states at scales from large river basins to the entire globe. It is grid based model which quantifies the dominant hydro-meteorological process taking place at the land surface atmospheric interface. Further details regarding VIC could be found in Liang et al. 1994, 1996; Nijssen et al. 1997; Lohmann et al. 1998a,b; Cherkauer and Lettenmaier 1999; Maurer et al. 2001a,b; Liang and Xie 2003, Aggarwal et al. 2013. In the present analysis, the model was forced with NCEP/NCAR Reanalysis daily meteorological data on precipitation, maximum temperature, minimum temperature and wind speed of period 1977 to 2006. However, the topographic parameters were derived from Cartosat - 1 DEM available at $30 \quad \mathrm{~m}$ resolution (http://bhuvan.nrsc.gov.in/data/download/index.php?c=s\&s=C1 $\& p=c d v 3 r 1 \& g=)$. Whereas soil properties were derived from National Bureau of Soil Survey and Land Use Planning (NBSS\&LUP) at 1:250,000 scale. The vegetation information was extracted from land use land cover generated under Indian Space Research Organisation Geosphere Bioshpere Programme at 1: 250,000 scale. The model was run in energy balance mode. The model was later calibrated at Pong Reservoir outlet against the observed data procured from the Bhakra Beas Management Board.

However, in this constantly changing environment, the availability and distribution of water will vary in space and time. Climate change will affect water resources through its impact on the quantity, variability, timing, form, and intensity of precipitation. The assessment of hydrologic responses to climate change is required in watershed management and planning to protect water resources and environmental quality. Additional effects of global climate change that have important implications for water resources include increased evaporation rates, a higher proportion of precipitation received as rain, rather than snow, earlier and shorter runoff seasons, increased water temperatures, and decreased water quality in both inland and coastal areas all over the world.

In this regard, the different climatic scenarios RCP 4.5 and 8.5 taken from Swedish Meteorological and Hydrological Institute's (SMHI) Coordinated Regional Downscaling Experiment (CORDEX) node by Rossby Centre regional atmospheric model (RCA) by downscaling Geophysical Fluid Dynamics Laboratory (GFDL) GCMs at $0.44 \mathrm{deg}$ at daily time scale for period 2006 to 2100 were analysed for Beas Basin. It has been observed that all the water balance components namely runoff, evapotranspiration (ET), baseflow are showing an increasing trend through out the century. However, the snow parameters like snow depth, snow melt and snow water equivalent are showing decreasing trend.

\section{STUDY AREA}

The study area for this work is Beas basin upto pong dam (figure 1). This area of Beas river basin encompasses an area of $12,417 \mathrm{~km}^{2}$ and lies between longitudes $75^{\circ} 84^{\prime} \mathrm{E}$ to $77^{\circ} 88^{\prime} \mathrm{E}$ and latitudes $31^{\circ} 41^{\prime} \mathrm{N}$ to $32^{\circ} 46^{\prime} \mathrm{N}$ with outlet point, $31^{\circ} 97^{\prime} \mathrm{N}$, $75^{\circ} 95^{\prime}$ E, at Pong dam in Kangra district, Himachal Pradesh state of India.

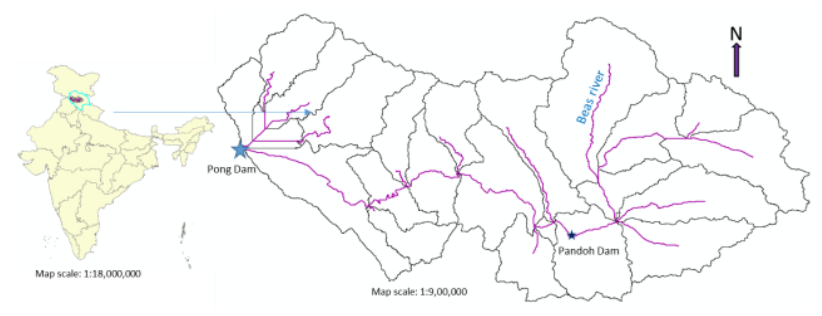

Figure 1: Study area, Beas basin up to Pong dam in Himachal Pradesh state of India.

The Beas River is one of the major rivers under the Indus basin. It originates in the upper Himalayas from Beas Kund near Rohtang Pass at an elevation of 3,960 m in Himachal Pradesh and flows south through the Kullu valley, receiving tributaries from the flanking mountains (figure 1), and then enters the Punjab plains to meet the Satluj at Harike. The total length of its course is about $460 \mathrm{~km}$. The catchment area of Beas River is about $20,303 \mathrm{~km}^{2}$ out of which only $777 \mathrm{~km}^{2}$ is under permanent snow and glaciers (http://india-wris.nrsc.gov.in). Parbati glacier is biggest glacier of this basin. The rest of the catchment area contributes water on account of rainfall especially from the high rainfall zone of Dharamsala, Palampur and Kangra. The bulk of the discharge of this river is received between the months of June and October due to concentration of rainfall in these months. Other details of Beas basin are listed in data types in sub-sections 3.1

\section{DATA AND METHODOLOGY}

\subsection{Data Used}

The data sets used are Land Use Land Cover (LULC) data from ISRO-GBP project at 1:250,000 scale (figure $2 b$ ), basin, slope, elevation from Cartosat-1 DEM version 3.1 at $30 \mathrm{~m}$ spatial 
resolution from BHUVAN geo-portal (figure 2c), soil data from National Bureau of Soil Survey and Land Use Planning, NBSS\&LUP at 1:250 000 scale (figure 2d). Observed discharge data from BBMB for period 2006-2014 was used for validation of current scenarios data.

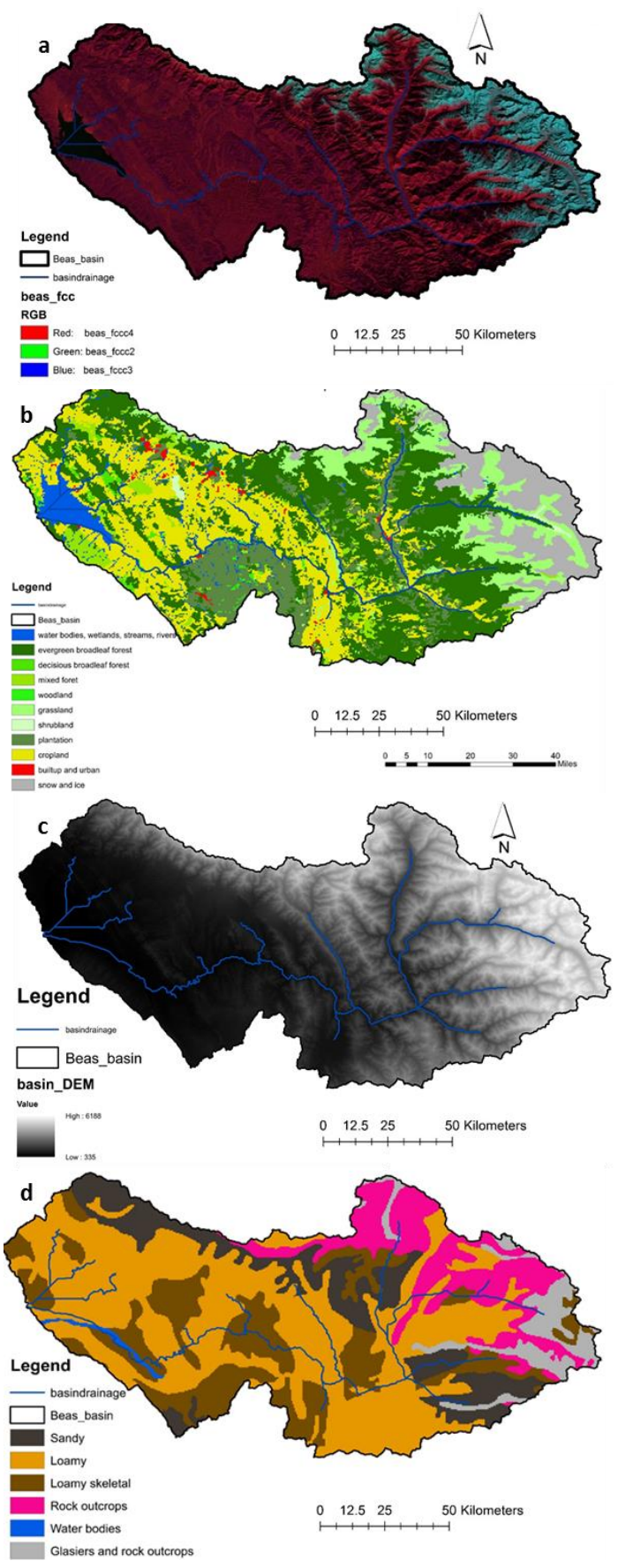

Figure 2a: False color composite image of Beas basin, b: LULC map, c: DEM map, and d: soil map of study area.

The LULC map of year 2005 (ISRO-GBP) is comprised of water body, evergreen broad leaf forest, deciduous broad leaf forest, mixed forest, woodland, grassland, shrub land, plantation, cropland, built-up and snow-ice classes. The vegetation parameter file for VIC model was generated based on fractional area each LULC class cover in a particular grid along with its rooting depth. The other vegetation properties were taken from Global Land Data Assimilation System (GLDAS - http://ldas.gsfc.nasa.gov/gldas/) vegetation parameter database. However, the soil parameter was generated using NBSSLUP soil texture information. The soil related parameters were derived using pedo-transfer functions. The topographic parameters like elevation and slope were derived from Cartosat1 DEM version 3.1 and same has been furnished in soil parameter file. Permanent snow line of the basin lies above $5000 \mathrm{~m}$ and minimum snow line varies from 1800 to $2000 \mathrm{~m}$. The western side of the study basin i.e. low elevation area is mainly rain-fed.

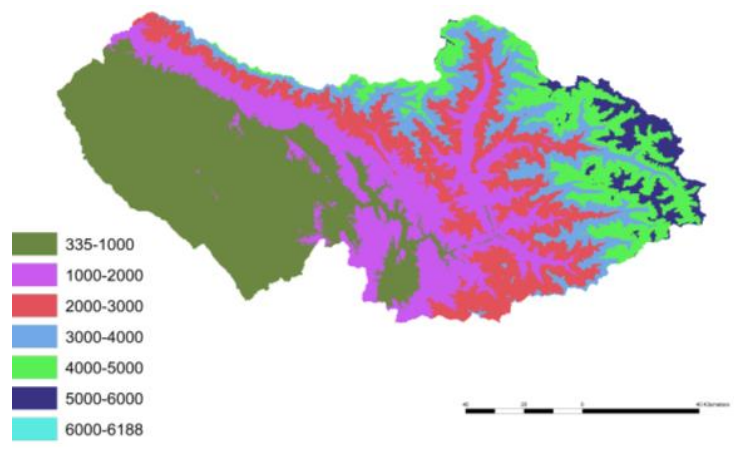

Figure 3. Elevation zone map of the basin

In case of future climate change scenarios there are number of data and surface fluxes layers, but only four parameters at daily scale were used in this study, which are, maximum temperature, minimum temperature, precipitation and wind speed. Future climate scenario data of South Asia at 0.44 degree grid size (WAS_GFDL_ESM2M_SMHI_RCAV2_DAILY) from IPCC5's RCP 4.5 and RCP 8.5 climate change scenarios for period 2006-2100 was used. This future climate change data is the downscaled data as part of CORDEX program, and was taken from Earth System Grid Federation, ESGF's data node at the National Supercomputer Centre (NSC), Linköping, Sweden (https://esg-dn1.nsc.liu.se/projects/esgf-liu/). The temperature trend data from RCP 8.5 and 4.5 derived from this model are shown in Figure $3 \mathrm{a} \& \mathrm{~b}$. The decadal trend of temperature under both the scenarios is shown in Figure 4.

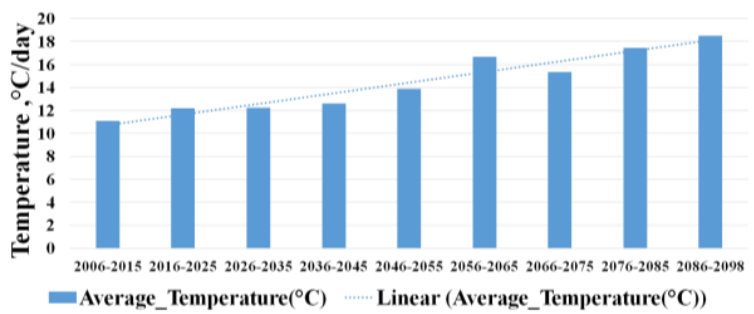

(a) RCP 8.5

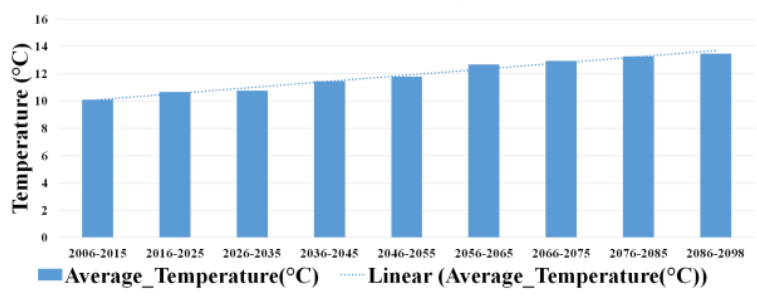

(b) RCP 4.5

Figure 4. The decadal temperature trend data from GFDLESM2M - RCAv4 for Beas Basin 


\subsection{Methodology Used}

The Beas basin has been analysed for studying the impact of climate change on its hydrology. The VIC hydrological model has been utilised for this purpose. As the model works at grid scale, the entire basin has been divided into 555 grids. The required input files such as meteorological forcing, soil parameter and vegetation parameter files were generated for each of these 555 run grids. Initially the model was forced with NCEP/NCAR reanalysis data on daily rainfall, maximum temperature, minimum temperature and wind speed. The soil parameter file generated using NBSSLUP data and the vegetation parameter file generated using ISRO-GBP LULC map of year 2005 were utilise for the modelling. The model was for period 1977 to 2006 and then it has been calibrated against the observed data of BBMB.

Later, the calibrated model was used for simulating the future climatic scenarios. In the present study, the RCP 8.5 and RCP 4.5 scenarios were studied. For future climate parameters the WAS_GFDL_ESM2M_SMHI_RCAV2_DAILY data has been used. The analysis has been carried out for period from 2006 to 2100. The overall flow chart of approach used is shown in Figure 5.

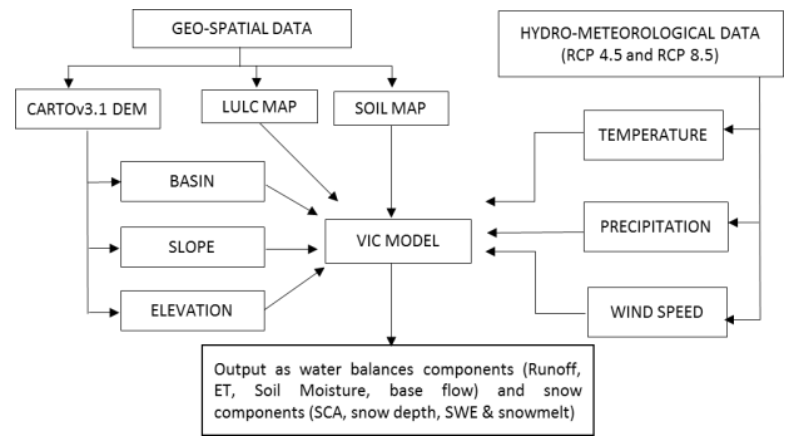

Figure 5: Flowchart of methodology used in the study

\section{RESULT AND DISCUSSIONS}

In the present study, the VIC hydrological model has been investigated to study impact of future climate change on Beas River basin hydrology. Initially, the model was run for period 1977-2006 using NCEP/NCAR reanalysis data and calibrated using BBMB observed discharge at Thalout gauging station. The calibrated model was later utilised to study the impact of climate change on hydrology of the basin. For future climatic parameters, the RCA downscaled GFDL GCMs climatic parameters on daily precipitation, maximum temperature, minimum temperature and wind speed at $0.44 \mathrm{deg}$ for scenarios RCP 4.5 and 8.5 were procured from SMHI generated under CORDEX for period 2006 to 2100 have been used. The decadal trend of precipitation under both the scenarios is shown in Figure 6.

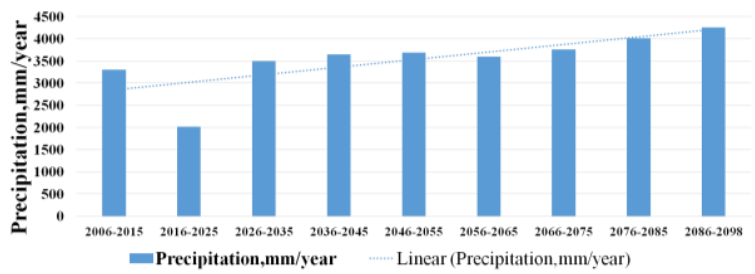

(a) RCP 8.5

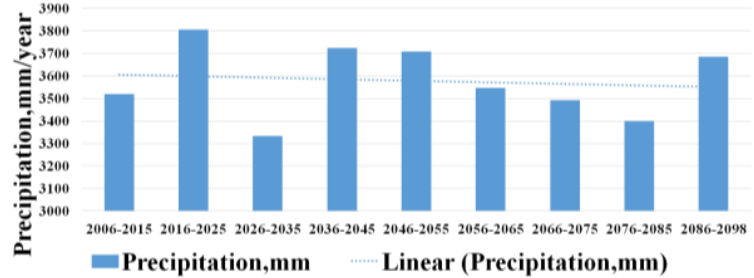

(b) RCP 4.5

Figure 6. The decadal precipitation trend data from GFDLESM2M - RCAv4 for Beas Basin

In was observed that under both the scenario temperature (Figure 4) is showing ever increasing trend whereas precipitation (Figure 6) is showing increasing trend under RCP 8.5 and decreasing trend under RCP 4.5. Definitely these changes in climatic parameters will affect hydrology of the basin.

The change in water balance components under each scenario are shown in Figure 7. All the components; ET, runoff, baseflow; are showing almost increasing trend.

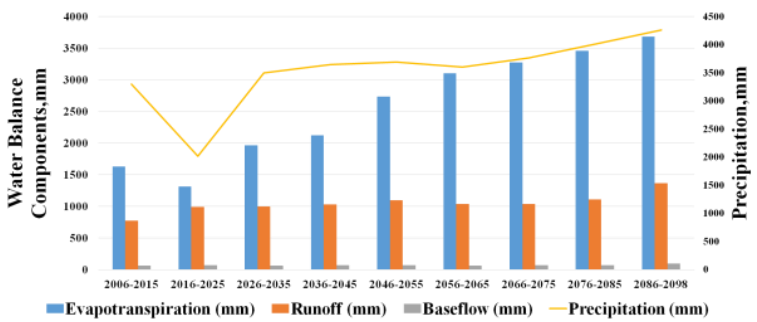

(a) RCP 8.5

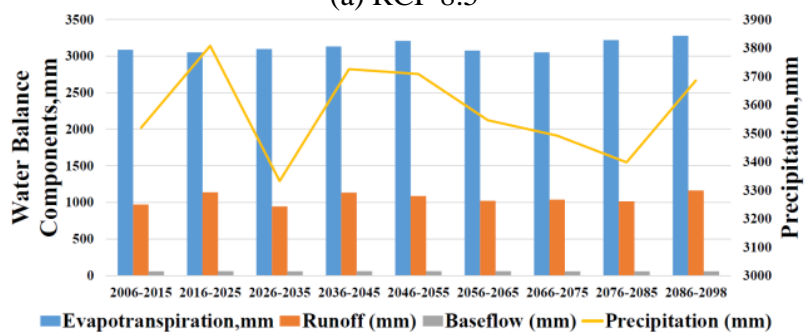

(b) RCP 4.5

Figure 7. Trend of each water balance components under each climatic scenario

As the temperature is showing increasing trend in both the scenarios, it is definitely going to affect the snow cover, snow depth, snow melt and snow water equivalent. Therefore, trend of each of these parameters has also been studied are shown in Figure 8-10.

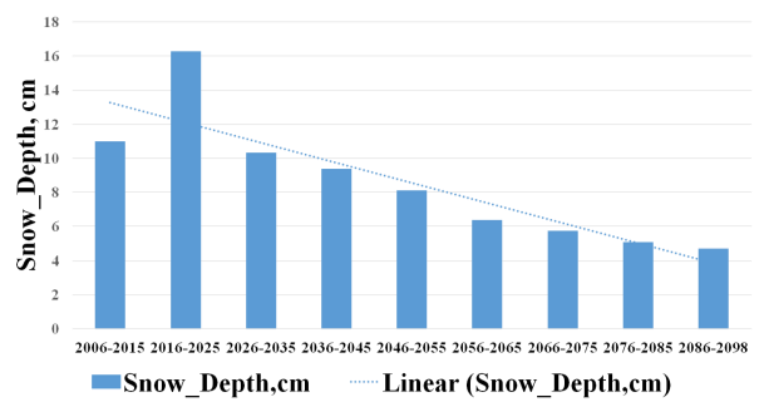

(a) RCP 8.5 


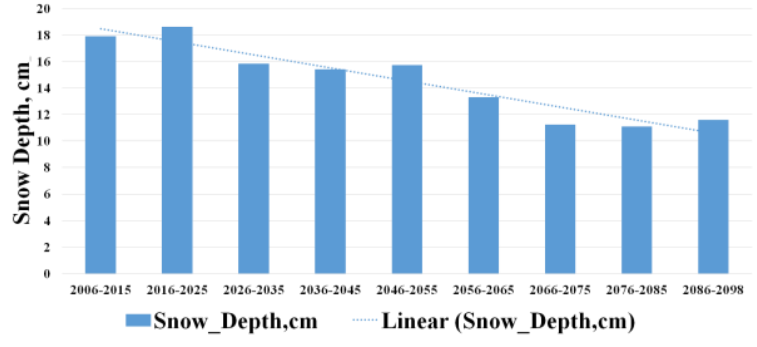

(b) RCP 4.5

Figure 8. Change in snow depth under each scenario for Beas Basin

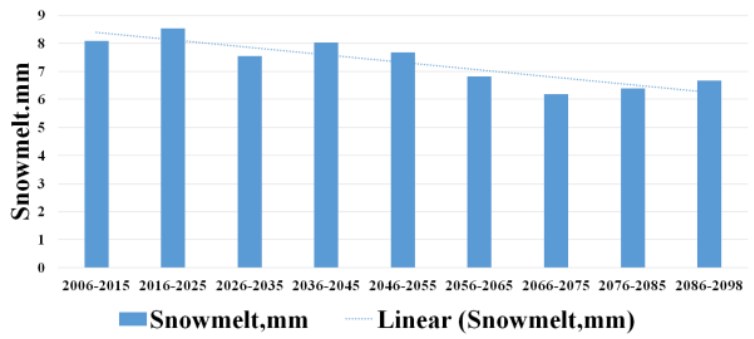

(a) RCP 8.5

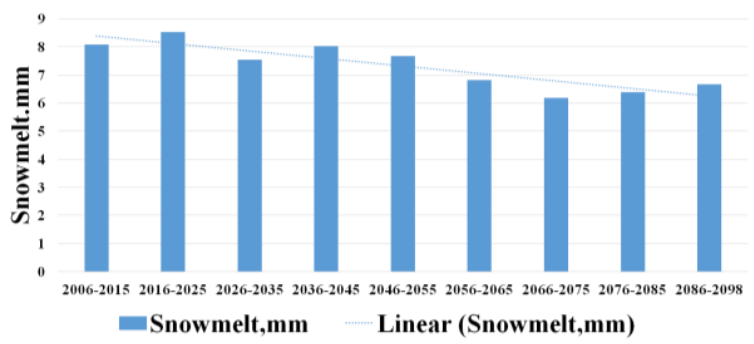

(b) RCP 4.5

Figure 9. Change in snow melt under each scenario for Beas Basin

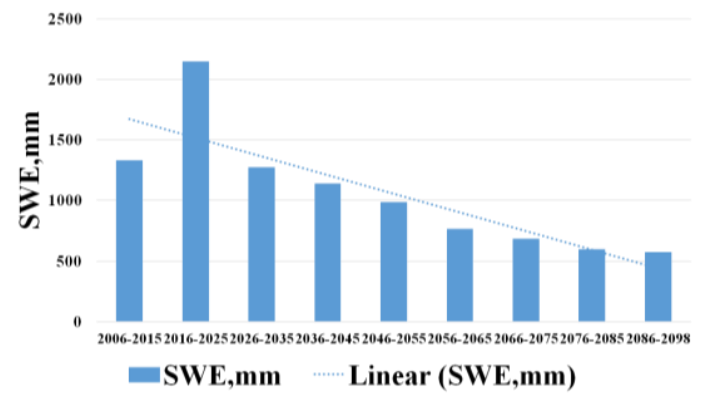

(a) RCP 8.5

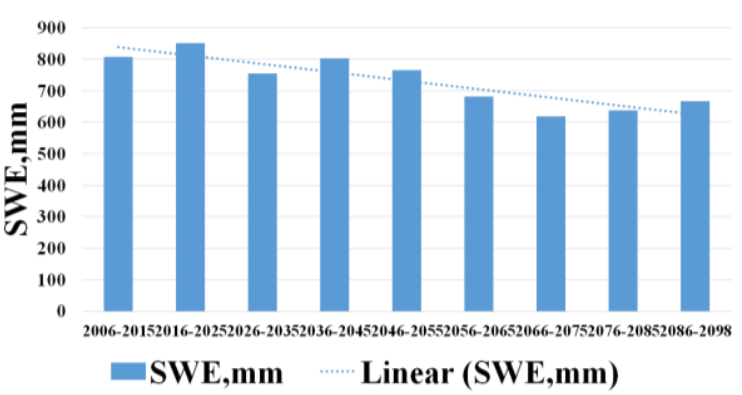

(b) RCP 4.5

Figure 10. Change in snow water equivalent under each scenario for Beas Basin
Later, the change in discharge at basin outlet near Pong Reservoir at Pong Dam has also been analysed using the VIC routing module. The change in discharge along with precipitation for each decade is shown in Figure 11.

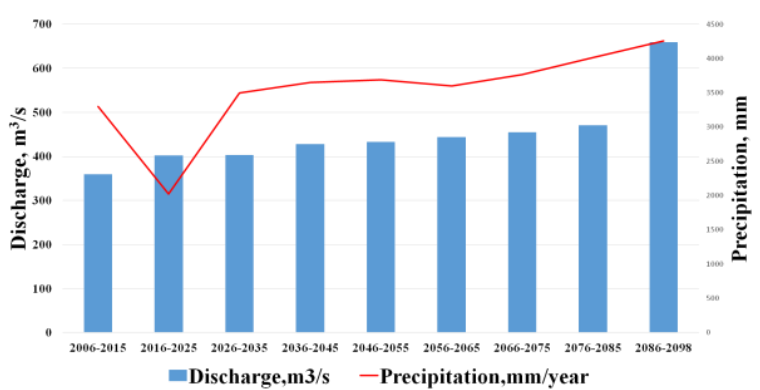

(a) RCP 8.5

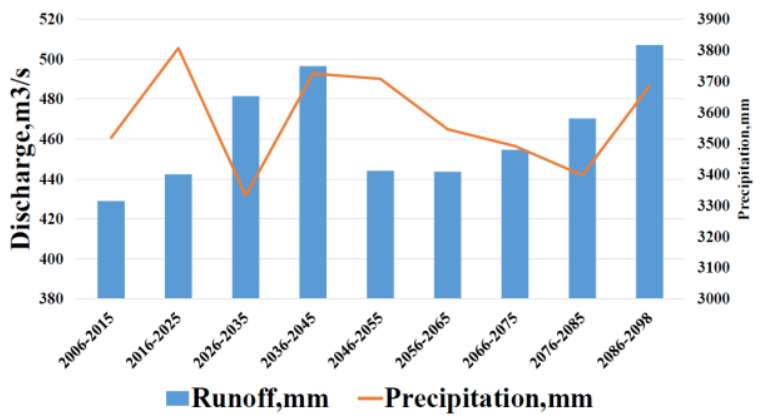

(b) RCP 4.5

Figure 11. The trend of discharge at Pong Dam under each scenario

The scenario RCP 8.5 is showing ever increasing trend of discharge. However, according to RCP 4.5 scenario, the discharge will increase up to mid century and then decrease and then increase by end of century.

The results averaged over basin can be helpful to study how regime of basin is changing with respect to climate change. For more in depth analysis, the results were analysed spatially for better understanding of these changes. Such studies will be helpful to identify the hot spots with regards to change. These kind of studies are important from planning point of view, the managers can plan their activities according to the change taking place in a particular location. This study has been done at 30 year time period, the change in temperature and precipitation in each 30 year time period is given in Table 1 .

Table 1 . The change in temperature and precipitation under

(a) RCP 8.5

\begin{tabular}{|c|c|c|c|c|}
\hline Categories & Period & Duration & Temperature, ${ }^{\circ} \mathrm{C}$ & Precipitation, mm \\
\hline Short term period & $2006-2035$ & 30 & 11.842 & 2940.255 \\
\hline Mid-term period & $2036-2065$ & 30 & 14.36 & 3646.666 \\
\hline \multirow{2}{*}{ Long term period } & $2066-2098$ & 32 & 17.10 & 4011.956 \\
\cline { 2 - 5 } & Change & & 5.26 & 293.5 \\
\hline & & 12 & 10.11 \\
\hline
\end{tabular}


(b) RCP 4.5

\begin{tabular}{|c|c|c|c|c|}
\hline Categories & Period & Duration & Temperature, ${ }^{\circ} \mathrm{C}$ & Precipitation, mm \\
\hline Short term period & $2006-2035$ & 30 & 10.58 & 3552.68 \\
\hline Mid-term period & $2036-2065$ & 30 & 11.97 & 3659.91 \\
\hline \multirow{2}{*}{ Long term period } & $2066-2098$ & 32 & 13.23 & 3525.29 \\
\cline { 2 - 5 } & Change & & 2.72 & -27.40 \\
\hline & & 7.62 & 0.25 \\
\hline
\end{tabular}

The corresponding spatial change in runoff pattern is shown in Figure 12.

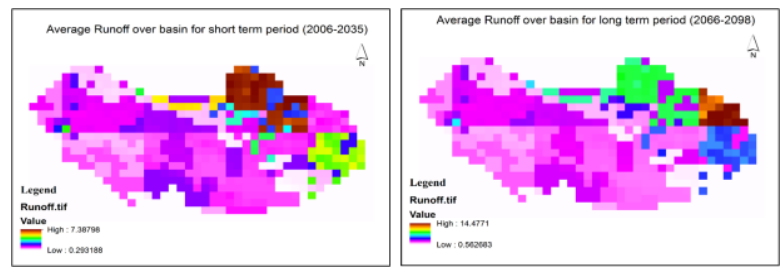

(a) RCP 8.5

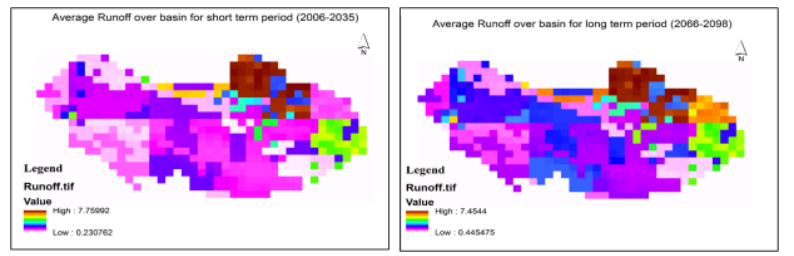

(b) RCP 4.5

Figure 12. Spatial change in runoff under each scenario

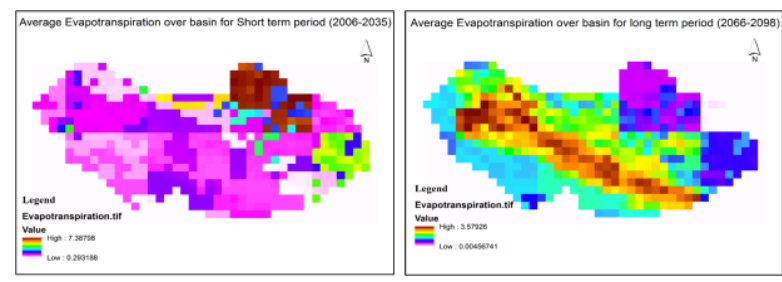

(a) RCP 8.5

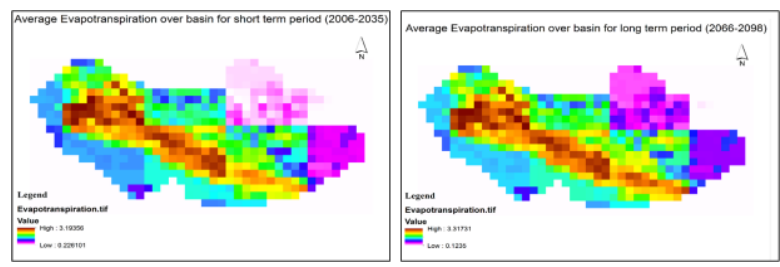

(b) RCP 4.5

Figure 13. Spatial change in ET under each scenario

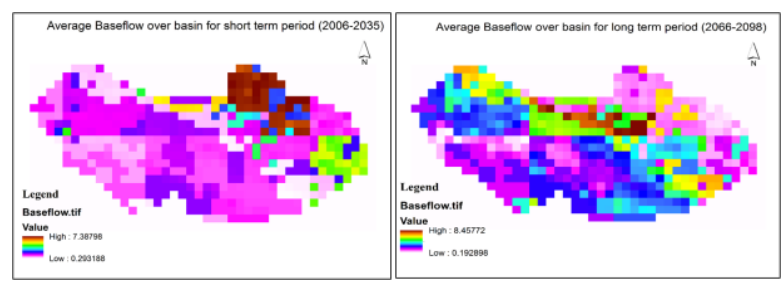

(a) RCP 8.5

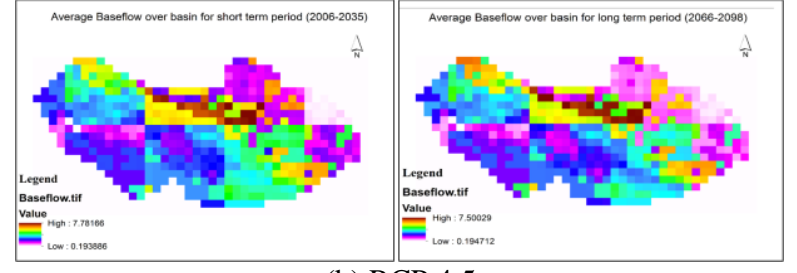

(b) RCP 4.5

Figure 14. Spatial change in baseflow under each scenario

Table 2. The change in water balance under each scenario

(a) RCP 8.5

\begin{tabular}{|c|c|c|c|c|c|}
\hline Categories & Period & Duration & Evapotranspiration, $\mathrm{mm}$ & Runoff, mm & Baseflow, $\mathrm{mn}$ \\
\hline Short term period & 2006-2035 & 30 & 1633.3 & 1115.24 & 63.40 \\
\hline Mid-term period & 2036-2065 & 30 & 2654.8 & 1054.685 & 64.12 \\
\hline Long term period & 2066-2098 & 32 & 3473.2 & 1503.86 & 75.24 \\
\hline \multicolumn{3}{|c|}{ Change } & 1840 & 509.81 & 11.84 \\
\hline \multicolumn{3}{|c|}{ Change in \% } & 23.71 & 13.87 & 5.84 \\
\hline
\end{tabular}

(b) RCP 4.5

\begin{tabular}{|c|c|c|c|c|c|}
\hline Categories & Period & Duration & Evapotranspiration, $\mathrm{mm}$ & Runoff, $\mathrm{mm}$ & Baseflow, mm \\
\hline Short term period & 2006-2035 & 30 & 3013.00 & 1017.70 & 58.66 \\
\hline Mid-term period & 2036-2065 & 30 & 3112.23 & 1080.36 & 58.9 \\
\hline Long term period & 2066-2098 & 32 & 3170.34 & 1503.86 & 57.76 \\
\hline \multicolumn{2}{|c|}{ Change } & & 157.34 & 54.21 & 1.38 \\
\hline \multicolumn{2}{|c|}{ Change in \% } & & 1.69 & 1.71 & 0.78 \\
\hline
\end{tabular}

In all the cases, each water balance component is showing increasing trend. The runoff is showing increasing trend may because of increase in precipitation, whereas, ET is showing increasing trend as temperature is increasing in all the yars to come. However, all the snow parameters are showing decreasing trend. This is due to increase in temperature parameter in the future climatic conditions. Due to increase in temperature, it will not be favourable condition for snowfall, so it will mostly be rainfall in the basin. Therefore, the snow parameters are showing decreasing trend. Moreover, due to increase in temperature snow melt will be more in the basin.

\section{CONCLUSIONS AND RECOMMENDATIONS}

In the present study, Beas Basin which is located in Himachal Pradesh, India has been studied for impact of climate change on its hydrology. Beas basin is one of the major river basin of Indus river system. The upper part of basin is mostly snow fed and remains snow cover through out the year. As indicated in many climate change studies, the snow pattern will mostly be affected by climate change, it was necessary to study such basins. For hydrological simulation, the VIC hydrological model has been used. Initially, the VIC model has been run for period 1977 to 2006 using NCEP/NCAR Reanalysis data on daily precipitation, daily temperature and daily wind speed. The model was then calibrated against the observed discharge available with BBMB. Later, in the present study, the hydrologic sensitivity of precipitation, temperature, runoff, ET, baseflow and discharge correspond to climate change has been evaluated for Beas Basin. The different climatic scenarios RCP 4.5 and 8.5 taken from Swedish Meteorological and 
Hydrological Institute's (SMHI) Coordinated Regional Downscaling Experiment (CORDEX) node by Rossby Centre regional atmospheric model (RCA) by downscaling Geophysical Fluid Dynamics Laboratory (GFDL) GCMs at 0.44 deg at daily time scale for period 2006 to 2100 were analysed. It was noticed that both temperature and precipitation may increase in future. Temperature will rise by around $12 \%$ and $7 \%$ under RCP 8.5 and RCP 4.5, respectively. However, precipitation will increase around $10.11 \%$ and $0.25 \%$ under each scenario. The basin was simulated through well calibrated VIC hydrological model for period of 2006 to 2100. The results showed that snow parameters are more sensitive to climate change. The increase of around $13.87 \%$ and $1.71 \%$ was observed in runoff for scenario RCP 8.5 and RCP 4.5, respectively. This may be attributed due to increase in precipitation. Whereas, an increase of approximately $23.71 \%$ and $1.69 \%$ was observed in ET under each scenario. It may be because of increase in temperature in both the scenarios. Slight increase in baseflow has also been observed. The snow parameters are showing decreasing trend as temperature is going to increase in each scenario. It will be not be favourable condition for snowfall, so the basin will mostly have rainfalls. Snow cover will be less and snowmelt will be more.

The current study is the initial step in creating an ensemble of climate change projections for hydrological water balance and snow components for Indian River systems especially for snowglacier fed rivers. One limitation of this study is use of LULC map of 2015 which is kept same in all 100 years simulations, whereas LULC is bound to change, which can impact on various components of water balance. Second limitation is in VIC model, as our basin has some areas under permanent snow and glaciers, current vegetation library of VIC do not consider this as one of the LULC classes. This can cause reduction in overall SCA and snow/glacier melt runoff in head water streams of the basin.

\section{ACKNOWLEDGEMENTS}

Authors acknowledge the support from Director, Indian Institute of Remote Sensing (IIRS) and Director, Snow and Avalanche Studies Establishment (SASE) for their valuable suggestions and support to complete this research work. This work is done as part of Indian Space Research Organization (ISRO) funded Earth Observation and Applications Mission (EOAM) project on "Monitoring and assessment of ecosystem processes and services in North-Western Himalaya, sub-theme 4 on water resources status and availability". Satellite data of MODIS SCA product was download from National Snow and Ice Data Centre (NSIDC), AWIFS SCA product was taken from Bhuvan-open EO data portal and Future climate change data was taken from ESGF's Swedish Meteorological and Hydrological Institute (SMHI) CORDEX data node.

\section{REFERENCES}

Aggarwal, S. P., Garg, V., Gupta, P. K., Nikam, B. R., Thakur, P. K., Roy, P. S. 2013. Runoff potential assessment over Indian landmass: A macro-scale hydrological modeling approach. Current Science, 104(7), 950-959.

Cherkauer, K. A., Lettenmaier, D. P. 1999. Hydrologic effects of frozen soils in the upper Mississippi River basin. J Geophys Res 104(D16):19599-19610.
CWC 2009. Integrated Hydrological Data Book (Non-Classified River Basins). Hydrological Data Directorate, Information System Organisation, Water Planning \& Projects Wing, Central Water Commission, Govt. of India, New Delhi.

CWC 2012. Integrated Hydrological Data Book (Non-Classified River Basins). Hydrological Data Directorate, Information System Organisation, Water Planning \& Projects Wing, Central Water Commission, Govt. of India, New Delhi.

Evans, J.P., 2011. CORDEX - An international climate downscaling initiative, 19th International Congress on Modelling and Simulation, Perth, Australia, 12-16 December 2011, http://mssanz.org.au/modsim2011, pp. 7.

Garg, N.K. and Hassan, Q. 2007. Alarming Scarcity of Water in India. Current Science 93(7):932 - 941.

Gosain, A.K., Rao, A. and Basuray, D. 2006. Climate change impact assessment on hydrology of Indian river basins. Current Science 90(3):346-353.

Gupta, S.K. and Deshpande, R.D. 2004. Water for India in 2050: first-order assessment of available options. Current Science 86(9):1216-1224.

Liang, X., Lattenmaier, D.P., Wood, E.F., and Burgess, S.J. 1994. A simple hydrologically based model of land surface, water, and energy flux for general circulation models. J. Geophys. Res. 99(D7):14415-14428.

Liang, X., Lettenmaier, D.P., and Wood, E.F. 1996. Onedimensional statistical dynamic representation of subgrid spatial variability of precipitation in the two-layer variable infiltration capacity model. J. Geophys. Res. 101(D16):21403-21422.

Liang, X., and Xie, Z.H. 2003. Important factors in landatmosphere interactions: surface runoff generations and interactions between surface and groundwater. Global Planet Change 38(1-2):101-114.

Lohmann, D., Raschke, E., Nijssen, B., and Lettenmaier, D.P. 1998a. Regional scale hydrology: I. Formulation of the VIC-2L model coupled to a routing model. Hydrological Sciences Journal 43(1):131-141.

Lohmann, D., Raschke, E., Nijssen, B., and Lettenmaier, D.P. 1998b. Regional scale hydrology: II. Application of the VIC-2L model to the Weser river, Germany. Hydrological Sciences Journal 43(1):143-158.

Mall, R.K., Bhatla, R., and Pandey, S.N. 2007. Water Resources in India and Impact of Climate Change. Jalvigyan Sameeksha 22:157 - 176.

Marzhan, S., 2016. Estimation of water balance components on Beas river basin in current and future climate scenarios, Post Graduate Diploma (PGD) project work of CSSTEAP, RS-GIS course of CSSTEAP, IIRS Dehradun, India. 45 p.

Maurer, E.P., O'Donnell, G.M., Lettenmaier, D.P., and Roads, J.O. 2001a. Evaluation of the Land Surface Water Budget in NCEP/NCAR and NCEP/DOE Reanalyses using an Off-line Hydrologic Model. J Geophys Res. 106(D16):17,841-17,862.

Maurer, E.P., O'Donnell, G.M., Lettenmaier, D.P., and Roads J.O. 2001b. Evaluation of NCEP/NCAR reanalysis water and energy budgets using macroscale hydrologic model simulations. 
In: (Lakshmi V, Albertson J, Schaake J (eds) Land Surface Hydrology, Meteorology, and Climate: Observations and Modeling. Water Sci. Appl. 3:137-158, AGU, Washington, D. C., doi:10.1029/WS003p0137.

Mujumdar, P.P. 2008. Implications of Climate Change for Sustainable Water Resources Management in India. Physics and Chemistry of the Earth 33:354 - 358 .

Nijssen, B.N., Lettenmaier, D.P., Liang, X., Wetzel, S.W., and Wood, E.F. 1997. Streamflow simulation for continental-scale river basins. Water Resour Res. 33(4):711-724.

Tebaldi, C., Smith, R., Nychka, D. and Mearns, L., 2005. Quantifying uncertainty in projections of regional climate change: A Bayesian approach to the analysis of multimodel ensembles, Journal of Climate, 18(10), pp. 1524-1540.

UNESCO/WMO 1992. International Glossary of Hydrology. Second edition. UNESCO/WMO.

Uppala, S. M., Dee, D., Kobayashi, S., Berrisford, P. and Simmons, A., 2008. Towards a climate adapt assimilation system: status update of ERA-Interim, ECMWF Newsletter, 115 , pp. 12-18.

van der Linden, P., and Mitchell J., Eds., 2009. ENSEMBLES: Climate change and its impacts, Summary of research and results from the ENSEMBLES project, Met Office Hadley Centre, Exeter, UK. 